\title{
The Role of Fusion Technique of Computed Tomography and Non-echo-planar Diffusion-weighted Imaging in the Evaluation of Surgical Cholesteatoma Localization
}

\section{Kolesteatomun Cerrahi Lokalizasyonunun Değerlendirilmesinde Bilgisayarlı Tomografi ve Difüzyon Ağırlıklı Non-eko-planar Görüntülemenin Füzyon Tekniğinin Rolü}

\author{
(1) Ayse Ozlem BALIK1, (1) Lutfu SENELDIR2, (1) Aysegul VERIM², (1) Sema ZER TOROS2
}

University of Health Sciences Turkey, Haydarpasa Numune Training and Research Hospital, Clinic of Radiology, Istanbul, Turkey

2University of Health Sciences Turkey, Haydarpasa Numune Training and Research Hospital, Clinic of Otorhinolaryngology, Istanbul, Turkey

\begin{abstract}
Objective: In recent years, the fusion of computed tomography (CT) and non-echo-planar diffusion-weighted magnetic resonance imaging (nonEPI DWI) has been preferred in cholesteatoma localizations. This study aimed to investigate the role of CT and non-EPI DWI fusion imaging in cholesteatoma localizations.

Methods: This retrospective study included 39 patients who underwent chronic otitis media operation [mean age of $35.10 \pm 15.33$ years ( $18-67$ years), $64.1 \%$ female, and $35.9 \%$ male] and had preoperative high-resolution temporal bone CT and non-EPI DWI examinations. Images were sent to the Advantage Workstation VolumeShare 7 for fusion. These selected images were fused on the workstation and were manually corrected by the radiologist. The sensitivity, specificity, positive and negative predictive values, and diagnostic accuracies of fused images of CT and non-EPI DWI were evaluated according to anatomic cholesteatoma localizations based on surgical data.

Results: The sensitivity, specificity, positive and negative predictive values and diagnostic accuracies of non-EPI DWI for detecting cholesteatomas were $97.14 \%, 75.00 \%, 97.14 \%, 75.00 \%$, and $94.87 \%$, respectively. Three true-negative, one false-positive, and one false-negative case were observed according to surgical results in detecting the presence of a cholesteatoma with non-EPI DWI. Moderate agreement was determined between the surgical and radiological results in detecting the presence of a cholesteatoma ( $k=0.721)$. Detecting the lesion of localization on the fused images compared to surgical found an almost perfect agreement in the mastoid antrum $(\mathrm{k}=0.948)$, strong agreement in the hypotympanum and mastoid cells $(\mathrm{k}=0.894)$, moderate agreement in the epitympanum $(\mathrm{k}=0.653)$, and weak agreement in those in the mesotympanum $(\mathrm{k}=0.540)$. Conclusions: The surgeons' determinations are supported by the guidance of temporal CT and non-EPI DWI fused images. Therefore, preferring the fusion imaging technique could increase the quality of life by reducing unnecessary operations.

Keywords: Cholesteatoma, multidetector computed tomography, diffusion magnetic resonance imaging, echo-planar imaging
\end{abstract}

öz

Amaç: Kolesteatom lokalizasyonunda bilgisayarlı tomografi (BT) ile difüzyon ağırlıklı non-eko-planar manyetik rezonans görüntüleme (nEDAG) füzyonu son yıllarda tercih edilmektedir. Bu çalışma, kolesteatom lokalizasyonunda BT ve nEDAG ile füzyon görüntülemenin rolünü araştırmayı amaçlamaktadır.

Yöntemler: Bu retrospektif çalışmaya, ameliyat öncesi yüksek çözünürlüklü temporal kemik BT ve nEDAG tetkikleri olan 39 kronik otitis media hastası [ortalama yas 35,10 $\pm 15,33$ yıl (18-67 yıl), \%64, kadın, \%35,9 erkek] dahil edildi. Görüntüler, füzyon için Advantage Workstation VolumeShare 7'ye gönderildi. Seçilen bu görüntüler iş istasyonunda aynı düzlemlerde birleștirildi ve radyolog tarafından manuel olarak düzeltildi. BT ve nEDAG birleştirilmiş görüntülerle kolesteatom varlığı ve anatomik lokalizasyonlarının duyarlılık, özgüllük, pozitif ve negatif prediktif değerleri ve tanısal doğrulukları, cerrahi verilere dayalı olarak değerlendirildi.

Bulgular: Kolesteatomları saptamada nEDAG'nin duyarlılığı, özgüllüğü, pozitif ve negatif prediktif değerleri ve tanısal doğrulukları sırasıyla $\% 97,14, \% 75,00, \% 97,14, \% 75,00$ ve $\% 94,87$ idi. nEDAC ile kolesteatom varlığının saptanmasında cerrahi sonuçlara göre üç gerçek negatif, bir yanlış pozitif ve bir yanlış negatif olgu gözlendi. Kolesteatom varlığının saptanmasında cerrahi ve radyolojik sonuçlar arasında önemli bir uyum vardı $(k=0,721)$. Birleştirilmiş görüntülerde, lezyonların lokalizasyonu cerrahi sonuçlarla karşılaștırıldığında, mastoid antrumda mükemmel $(k=0,948)$, mastoid hücrelerde ve hipotimpanumda güçlü $(k=0,894)$, epitimpanumda orta $(k=0,653)$ düzeyde bir uyum varken, mezotimpanumdakilerde zayıf düzeyde uyum vardı $(k=0,540)$.

Sonuçlar: Cerrahların saptamaları, temporal BT ve nEDAG'nin birleştirilmiş görüntülerinin rehberliğinde desteklenmektedir. Bu nedenle füzyon görüntüleme tekniğinin tercih edilmesi, gereksiz operasyonları azaltarak yaşam kalitesini artırabilir.

Anahtar kelimeler: Kolesteatom, multidedektörlü bilgisayarlı tomografi, difüzyon manyetik rezonans görüntüleme, eko-panar görüntüleme
Address for Correspondence: A. O. Balik, University of Health Sciences Turkey, Haydarpasa Numune

Training and Research Hospital, Clinic of Radiology, Istanbul, Turkey

E-mail: ozlemrad @gmail.com ORCID ID: orcid.org/0000-0002-5703-6720
Received: 09 November 2021

Accepted: 08 January 2022

Online First: 14 January 2022

Cite as: Balik AO, Seneldir L, Verim A, Zer Toros S. The Role of Fusion Technique of Computed Tomography and Non-echo-planar Diffusion-weighted Imaging in the Evaluation of Surgical Cholesteatoma Localization. Medeni Med J 2022;37:13-20

${ }^{\circledR}$ Copyright 2022 by the Istanbul Medeniyet University / Medeniyet Medical Journal published by Galenos Publishing House.

Licenced by Creative Commons Attribution-NonCommercial 4.0 International (CC BY-NC 4.0) 


\section{INTRODUCTION}

Preoperative detection and localization of cholesteatoma are greatly important for its high recurrence rate and complication risks. The incidence of recurrent cholesteatoma during the 5-year postoperative follow-up period was reported as $57-61 \%$, It may cause bony erosion, hearing loss, vertigo, and intracranial infections. Cholesteatomas often localize the attic with a tiny retraction of the pars flaccida and an intact pars tensa of the tympanic membrane ${ }^{3,4}$. Depending on the localization, the surgeon may prefer a transcanal endoscopic approach or other surgical techniques. A cholesteatoma that is located in the mesotympanum or epitympanum is usually treated with pure endoscopic technique, whereas otolaryngologists usually prefer the combination of microscopic and endoscopic techniques when the mastoid is involved.

At this point, the presence of cholesteatoma and an accurate description of its spatial extent become important for accurate treatment approach ${ }^{5}$. Several imaging methods currently exist for cholesteatoma evaluations. Computed tomography (CT) yields highquality imaging of the spatial resolution and bony details of the lesion but fails to differentiate the cholesteatoma from other lesions, such as granulations, fibrotic, scarring changes, mucous secretions, or fluid ${ }^{6,7}$. Magnetic resonance imaging (MRI) is a non-ionizing imaging technique that is used to evaluate patients with surgical history who are suspected to have residual or recurrent disease. Contrarily, cholesteatomas are known to be reliably detected and distinguished from soft tissues in the middle ear cleft in non-echoplanar diffusion-weighted MRI (non-EPI DWI) due to their high keratin content ${ }^{8-10}$. Additionally, non-EPI DWI does not necessitate intravenous contrast injection. However, none of these methods alone gives excellent results in lesion detection. Therefore, the trend toward the use of fusion techniques in evaluating cholesteatomas has been increasing in the last decade ${ }^{11-13}$. Fused images reveal the extent of the lesion in the middle ear and play a significant role in determining the correct approach for otologic surgeons. However, this technique requires additional time for the fusion of images. Additionally, the literature data about the efficacy and necessity of fusion techniques on cholesteatoma localization are limited.

Therefore, this study aimed to investigate the emerging role of $C T$ and non-EPI DWI fusion imaging in preoperative detection and correct cholesteatoma localization.

\section{MATERIALS and METHODS}

The study was approved by the Clinical Research Ethics Committee of the Haydarpasa Numune Training and Research Hospital (decision no: KAEK 2021/265, date: 04.10.2021). Signed informed consent forms were waived due to the retrospective cross-sectional design of the study.

\section{Patients}

This study included 39 patients (25 males and 14 females) who could have both CT and non-EPI DWI MRI in the last 4 weeks of the preoperative period among those operated for suspected cholesteatoma between April 1, 2014-2020.

Patients with concomitant illness (malignancy, hepatic, psychiatric, endocrine, or other major systemic diseases), children, drug users, and smokers were excluded from the study.

\section{Imaging Technique}

High-resolution CT was performed with the standard temporal bone protocol using a 128 SL Optima CT 660 scanner (General Electric Medical Systems, Milwaukee, WI, USA). The scanning parameters were as follows: $2 \times 0.625 \mathrm{~mm}$ detector configuration, 0.625-1.0 mm slice thickness, $160 \times 160$ fields of view, $180 \mathrm{mAs}, 120 \mathrm{kVp}$, and 512 matrix.

MRIs were performed in a 1.5 T MRI scanner (General Electric-Optima 450 w -1.5 Tesla) using a standard 16-channel head coil. Non-EPI DWI images were acquired in the axial plane with a $3 \mathrm{~mm}$ thickness (TR: $3000 \mathrm{~ms}$; TE: 85 ms; Matrix: 128×128; B-value: 1000 s/mm²; imaging time: $4 \mathrm{~min})$. PROPELLER, a non-EPI DWI consisting of acquired images with periodically rotated overlapping parallel lines with enhanced reconstruction, was used.

\section{Imaging Evaluation}

Images were examined by the same radiologist who was blinded to the postoperative information of patients and had 17 years of experience in head and neck imaging to ensure the objectivity of evaluation. All images in DWI with diffusion restriction were investigated in bl000. With the absence of diffusion restriction, the image was considered a non-cholesteatomatous lesion. Apparent diffusion coefficient (ADC) measurements were performed from the brightest central part of the lesion, at b-1000, while keeping a standard $2 \mathrm{~mm}^{2}$ area of the region of interest. 
Preoperative CT and bl000 images of non-EPI DWI images from patients who are treated at our hospital for chronic otitis media were sent to the Advantage Workstation VolumeShare 7 (GE Healthcare Systems AWO1, Milwaukee, WI USA) through the picture archiving and communication system (PACS). The CT and MR images were combined on the workstation in the same planes (axial and coronal), and the image shifts during automated fusion were manually corrected by the radiologist to overlap the same anatomical regions as $C T$ and $M R$ images (mean evaluation time was approximately $15 \mathrm{~min}$ per patient). Following the fusion images that developed afterward, the regional cholesteatoma distribution was classified into five categories: epitympanic, mesotympanic, hypotympanic, mastoid antrum, and mastoid cellular. Finally, the fused images were saved in the PACS.

\section{Surgery}

Surgical results were obtained from the postoperative reports that are prepared by two experienced otologic surgeons who operated on the patients. These surgical reports described the presence and anatomic localization of lesions.

Then comparative evaluations were made between radiological and surgical localization of cholesteatoma.

\section{Statistical Analysis}

International Business Machines Corporation Statistical Package for the Social Sciences version 22 (IBM Corp. Released 2013. IBM SPSS Statistics for
Windows, Version 22.0. Armonk, NY: IBM Corp.) was used for statistical analysis. Descriptive statistical methods [mean, standard deviation (SD), median, frequency, percentage, minimum, and maximum] were used to evaluate the study data. The sensitivity, specificity, positive and negative predictive values, and diagnostic accuracy of CT and non-EPI DWI fused images that were compared based on surgical data were evaluated with diagnostic tests. The agreement of the presence of a lesion and lesion localization on radiology according to surgical reports were evaluated with McNemar's test, Cohen's Kappa coefficient test. Kappa values of 0.00-0.20 were considered as none, 0.21-0.39 as minimal, 0.40-0.59 as weak, 0.60-0.79 as moderate, $0.80-0.90$ as strong, and $0.90-1$ as almost perfect agreement. $\mathrm{P}$-values of $<0.05$ were considered statistically significant in all tests.

\section{RESULTS}

Of the 39 cases in the study, 64.1\% $(n=25)$ were males and $35.9 \%(n=14)$ were females. The mean age of the patients was $35.10 \pm 15.33$ years (18-67 years). Lesions were mostly detected in the epitympanum and are least observed in the mastoid antrum or mastoid cavity in both radiologic and surgical reports as shown in Figure 1.

\section{Imaging Features}

The mean lesion diameter was $5.90 \pm 3.78 \mathrm{~mm}(2-15 \mathrm{~mm})$ in the radiologic evaluation. All of the cholesteatomas were hyperintense on the T2-weighted series. The ADC values of lesions ranged between 0.56 and $1.44 \times 10^{-3}$

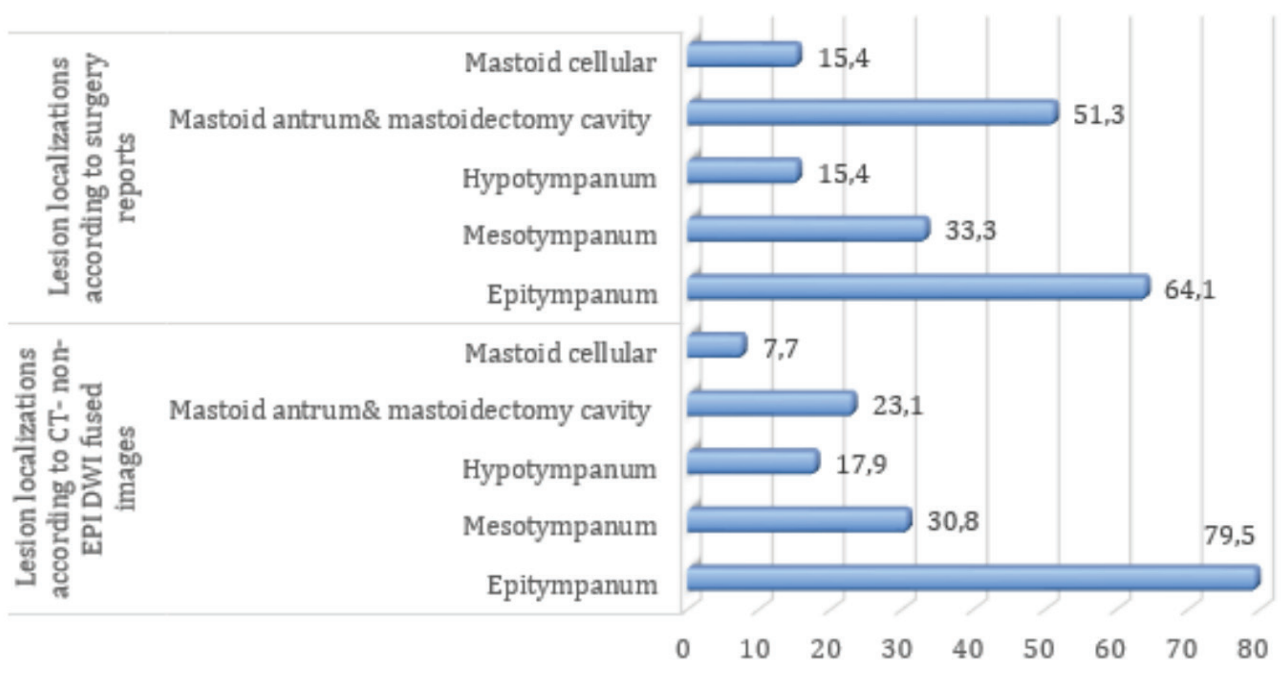

Figure 1. Lesion localization according to radiologic and surgical reports.

Non-EPI DWI: Non-echo-planar diffusion-weighted magnetic resonance imaging, CT: Computed tomography 
$\mathrm{mm}^{2} / \mathrm{s}$, with a mean of $0.84 \pm 0.21 \times 10^{-3} \mathrm{~mm}^{2} / \mathrm{s}$ (median \pm SD) (Table 1).

\section{Cholesteatoma Detection}

The sensitivity, specificity, positive and negative predictive values, and diagnostic accuracy of nonEPI DWI for cholesteatoma detections were 97.14\%, $75.00 \%, 97.14 \%, 75.00 \%$, and $94.87 \%$, respectively. A moderate agreement was determined between surgical and radiological results in detecting the presence of a cholesteatoma ( $k=0.721)$. Three true-negative, one falsepositive, and one false-negative case were observed according to surgical results in detecting the presence of a cholesteatoma with non-EPI DWI (Table 2).

\section{Lesion Localization}

The evaluation of fused images compared to the surgical results on lesion localization revealed an almost perfect agreement in the mastoid antrum ( $k=0.948)$, strong agreement in the hypotympanum and mastoid cells $(k=0.894)$, moderate agreement in the epitympanum ( $k=0.653)$, and weak agreement in those in the mesotympanum ( $\mathrm{k}=0.540$ ) (Table 3) (Figure 2). The evaluation of cholesteatoma localization revealed the most accurate results on hypotympanum, mastoid cells, and mastoid antrum (diagnostic accuracy $=97.44$ for all) on fusion technique (Table 4).

\begin{tabular}{|c|c|c|c|}
\hline & & $\mathbf{n}$ & Mean \pm SD \\
\hline Age & Min-max (median) & $18-67(33)$ & $35.10 \pm 15.33$ \\
\hline \multirow{2}{*}{ Gender } & Male & 25 & 64.1 \\
\hline & Female & 14 & 35.9 \\
\hline \multirow{2}{*}{ Localization } & Right & 16 & 41.0 \\
\hline & Left & 23 & 59.0 \\
\hline \multirow{3}{*}{$\mathrm{Tl}$} & Isointense & 5 & 13.2 \\
\hline & Hypointense & 33 & 86.8 \\
\hline & Hyperintense & - & - \\
\hline \multirow{3}{*}{$\mathrm{T} 2$} & Isointense & - & - \\
\hline & Hypointense & - & - \\
\hline & Hyperintense & 38 & 100 \\
\hline Lesion diameter (mm) & Min-max (median) & $2-15(4.5)$ & $5.92 \pm 3.76$ \\
\hline ADC value $\left(10^{-3} \mathrm{~mm}^{2} / \mathrm{s}\right)(\mathrm{n}=35)$ & Min-max (median) & $0.56-1.44(0.7)$ & $0.84 \pm 0.21$ \\
\hline
\end{tabular}

Table 2. Agreement of lesion detecting according to diffusion restriction on Non-EPI DWI with surgery results.

\begin{tabular}{|c|c|c|c|c|c|c|}
\hline & & \multicolumn{3}{|c|}{ Surgery result } & \multirow{3}{*}{ p-value* } & \multirow{3}{*}{ k-value } \\
\hline & & \multirow{2}{*}{\begin{tabular}{|l|} 
Absent \\
n (\%)
\end{tabular}} & \multirow{2}{*}{\begin{tabular}{|l|} 
Present \\
n (\%)
\end{tabular}} & \multirow{2}{*}{$\frac{\text { All }}{\text { n (\%) }}$} & & \\
\hline & & & & & & \\
\hline \multirow{3}{*}{$\begin{array}{l}\text { Presence of lesion according to diffusion } \\
\text { restriction on non-EPI DWI MR }\end{array}$} & Absent & $3(75.0)$ & $1(2.9)$ & $4(10.3)$ & \multirow{3}{*}{1.000} & \multirow{3}{*}{0.721} \\
\hline & Present & $1(25.0)$ & $34(97.1)$ & 35 (89.7) & & \\
\hline & All & $4(10.3)$ & $35(89.7)$ & $39(100)$ & & \\
\hline & SN \% & 97.14 & \multicolumn{2}{|c|}{ (95\% Cl: 85.08-99.92) } & & \\
\hline & SP \% & 75.00 & \multicolumn{2}{|c|}{ (95\% Cl: 19.41-99.36) } & & \\
\hline & PPV \% & 97.14 & \multicolumn{2}{|c|}{ (95\% Cl: 86.15-99.46) } & & \\
\hline & NPV $\%$ & 75.00 & \multicolumn{2}{|c|}{ (95\% Cl: 28.61-95.73) } & & \\
\hline & DA \% & 94.87 & \multicolumn{2}{|c|}{ (95\% Cl: 82.67-99.37) } & & \\
\hline
\end{tabular}




\section{DISCUSSION}

This retrospective cross-sectional study revealed good agreement and reliability of the fusion technique with surgical results in detecting cholesteatoma localizations. Additionally, a significant consistency was found between surgical and radiological results in detecting the presence of cholesteatoma using non-EPI DWI, which is consistent with the literature.
MRI techniques, such as non-EPI DWI, which were developed in the last years, started to take the place of invasive surgical interventions and are also used for cholesteatoma diagnosis and postoperative follow-up. Lingam and Bassett $^{8}$ revealed a pooled sensitivity and specificity of 0.91 and 0.92 , respectively, for detecting cholesteatoma on non-EPI DWI in their meta-analysis, which included 26 studies. Locketz et al. ${ }^{12}$ revealed that the diagnostic threshold of 2-3 $\mathrm{mm}$ for cholesteatomas

\begin{tabular}{|c|c|c|c|c|c|c|}
\hline \multirow{3}{*}{ Lesion localization } & \multirow{3}{*}{$\begin{array}{l}\text { Presence of lesion } \\
\text { according to fusion } \\
\text { imaging }\end{array}$} & \multicolumn{3}{|c|}{$\begin{array}{l}\text { Lesion localization according to surgery } \\
\text { reports, } \mathrm{n}(\%)\end{array}$} & \multirow{3}{*}{ p-value* } & \multirow{3}{*}{ k-value } \\
\hline & & Absent & Present & All & & \\
\hline & & n (\%) & n (\%) & n (\%) & & \\
\hline \multirow{3}{*}{ Epitympanum } & Absent & $5(12.8)$ & $1(2.6)$ & $6(15.4)$ & \multirow{3}{*}{0.625} & \multirow{3}{*}{0.653} \\
\hline & Present & $3(7.7)$ & 30 (76.9) & $33(84.6)$ & & \\
\hline & All & $8(20.5)$ & 31 (79.5) & $39(100)$ & & \\
\hline \multirow{3}{*}{ Mesotympanum } & Absent & $22(56.4)$ & $3(7.7)$ & $25(64.1)$ & \multirow{3}{*}{0.727} & \multirow{3}{*}{0.540} \\
\hline & Present & $5(12.8)$ & $9(23.1)$ & $14(35.9)$ & & \\
\hline & All & $27(69.2)$ & $12(30.8)$ & $39(100)$ & & \\
\hline \multirow{3}{*}{ Hypotympanum } & Absent & $33(84.6)$ & $1(2.6)$ & 34 (87.2) & \multirow{3}{*}{1.000} & \multirow{3}{*}{0.894} \\
\hline & Present & $0(0)$ & $5(12.8)$ & $5(12.8)$ & & \\
\hline & All & $33(84.6)$ & $6(15.4)$ & $39(100)$ & & \\
\hline \multirow{3}{*}{ Mastoid cells } & Absent & $33(84.6)$ & $1(2.6)$ & 34 (87.2) & \multirow{3}{*}{1.000} & \multirow{3}{*}{0.894} \\
\hline & Present & $0(0)$ & $5(12.8)$ & $5(12.8)$ & & \\
\hline & All & $33(84.6)$ & $6(15.4)$ & $39(100)$ & & \\
\hline \multirow{3}{*}{ Mastoid antrum } & Absent & $16(41)$ & $1(2.6)$ & $17(43.6)$ & \multirow{3}{*}{1.000} & \multirow{3}{*}{0.948} \\
\hline & Present & $0(0)$ & $22(56,4)$ & $22(56.4)$ & & \\
\hline & All & $16(41)$ & $23(59.0)$ & $39(100)$ & & \\
\hline
\end{tabular}

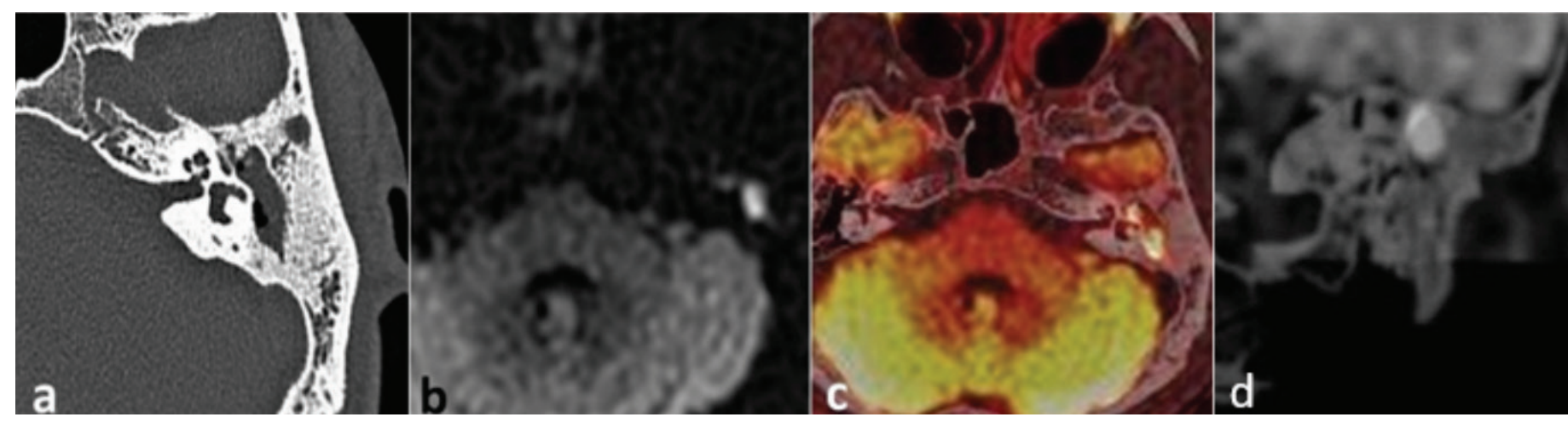

Figure 2. A 33-year-old patient with recurrent cholesteatoma in the operated left middle ear. (a) Axial computed tomography (CT), (b) non-echo-planar diffusion-weighted magnetic resonance imaging, (c) axial fused image, (d) coronal fused image. On CT, localized soft-tissue opacities are seen in the epitympanum, mesotympanum, and mastoid cavity. The fused image of the cholesteatoma was localized in the epitympanum, mesotympanum, hypotympanum, sinus tympani, and mastoid cavity, and these localizations were confirmed during surgery except for mesotympanum. 


\begin{tabular}{|c|c|c|c|c|c|}
\hline Lesion localization & $\begin{array}{l}\text { SN\% } \\
(95 \% \mathrm{CI})\end{array}$ & $\begin{array}{l}\text { SP\% } \\
(95 \% \mathrm{CI})\end{array}$ & $\begin{array}{l}\text { PPV\% } \\
(95 \% \mathrm{CI})\end{array}$ & $\begin{array}{l}\text { NPV\% } \\
(95 \% \mathrm{CI})\end{array}$ & $\begin{array}{l}\text { DA\% } \\
(95 \% \mathrm{CI})\end{array}$ \\
\hline Epitympanum & $\begin{array}{l}96.77 \\
(83.29-99.91)\end{array}$ & $\begin{array}{l}62.50 \\
(24.48-91.47)\end{array}$ & $\begin{array}{l}90.91 \\
(80.30-96.08)\end{array}$ & $\begin{array}{l}83.33 \\
(40.32-97.36)\end{array}$ & $\begin{array}{l}89.74 \\
(75.77-97.13)\end{array}$ \\
\hline Mesotympanum & $\begin{array}{l}75.00 \\
(42.81-94.51)\end{array}$ & $\begin{array}{l}81.48 \\
(61.91-93.70)\end{array}$ & $\begin{array}{l}64.29 \\
(43.33-80.90)\end{array}$ & $\begin{array}{l}88.00 \\
(73.02-95.20)\end{array}$ & $\begin{array}{l}79.49 \\
(63.53-90.70)\end{array}$ \\
\hline Hypotympanum & $\begin{array}{l}83.33 \\
(35.87-99.57)\end{array}$ & $\begin{array}{l}100.00 \\
(89.42-100.00)\end{array}$ & $\begin{array}{l}100.00 \\
(100.000-100.00)\end{array}$ & $\begin{array}{l}97.06 \\
(84.64-99.49)\end{array}$ & $\begin{array}{l}97.44 \\
(86.52-99.93)\end{array}$ \\
\hline Mastoid antrum & $\begin{array}{l}95.65 \\
(78.05-99.89)\end{array}$ & $\begin{array}{l}100.00 \\
(79.40-100.00)\end{array}$ & $\begin{array}{l}100.00 \\
(100.00-100.00)\end{array}$ & $\begin{array}{l}94.12 \\
(70.17-99.08)\end{array}$ & $\begin{array}{l}97.44 \\
(86.52-99.93)\end{array}$ \\
\hline Mastoid cells & $\begin{array}{l}83.33 \\
(35.87-99.57)\end{array}$ & $\begin{array}{l}100.00 \\
(89.42-100.00)\end{array}$ & $\begin{array}{l}100.00 \\
(100.00-100.00)\end{array}$ & $\begin{array}{l}97.06 \\
(84.64-99.49)\end{array}$ & $\begin{array}{l}97.44 \\
(86.52-99.93)\end{array}$ \\
\hline
\end{tabular}

SN: Sensitivity, SP: Specificity, PPV: Positive predictive value, NPV: Negative predictive value, DA: Diagnostic accuracy, Cl: Confidence interval

remains a limitation for $C T$ and non-EPI DWI fusion. In their series, 12 cases had two false-negatives in CT-MRI fusion images, one of which belonged to a re-operated patient with chronic ear disease who had a residual cholesteatoma smaller than $3 \mathrm{~mm}$. The other falsenegative lesion, $2 \times 3 \mathrm{~mm}$ in size, had intermediate signal intensity in non-EPI DWI. The time between image acquisition and surgery was 5 months, and by then, the lesion had enlarged to a visible size. The present study revealed that non-EPI DWI had high sensitivity (97.1\%) for detecting cholesteatomas. The high sensitivity of this study is thought to be due to skull base artifact minimization in non-EPI DWI, the special attention was shown in selecting the patients referred for surgery and the time between imaging and surgery. However, out of 39 lesions, four showed no diffusion restriction and three were true-negatives, leading to a specificity of $75 \%$. Our study revealed only one false-negative lesion of 2 $\mathrm{mm}$ in diameter, which was detected during surgery in the cavity of the mastoidectomy (Figure 3). As stated in many studies, wax, proteinaceous fluid, or bone dust/ powder can generate a high signal on the bl000 images and cause false-positive results ${ }^{14-16}$. The present study revealed one false-positive result using non-EPI DWI that resulted from the highly viscous lesion content in the temporal bone, which was surgically reported as an empyema (Figure 4).

Recently, the interpretation of the DWI together with the ADC map and the corresponding CT images has been recommended in radiological practice. ADC values are also useful in improving specificity and confidence levels in cholesteatoma diagnosis ${ }^{14}$. Cholesteatomas showed to have a significantly lower ADC value than non-cholesteatomatous soft-tissue ${ }^{13,16}$. Lingam et al. ${ }^{17}$

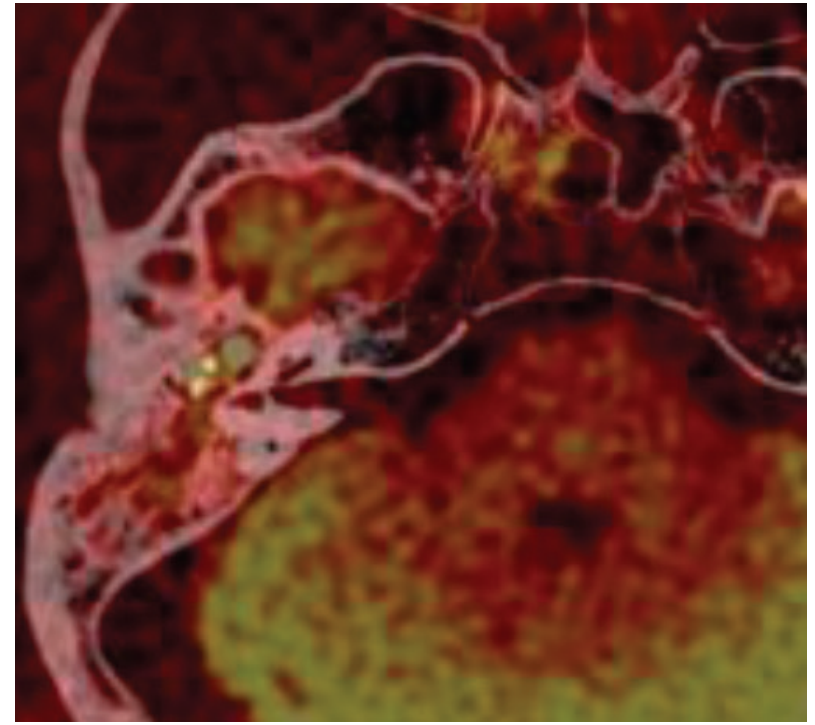

Figure 3. A fused image of a 29-year-old patient with recurrent cholesteatoma showing the soft-tissue opacities in the epitympanum, mesotympanum, mastoid resection cavity, and two nodular hyperintense lesions on bl000 diffusion-weighted magnetic resonance imaging (DWI) is suggestive cholesteatoma in the epitympanum and mesotympanum. No hyperintense lesion on b1000 DWI in the mastoid cavity. However, a little cholesteatoma was found in the mastoid resection cavity during the surgery.

reported that $A D C$ values on postoperative middle ear cholesteatoma $\left(0.7-0.9 \times 10^{-3} \mathrm{~mm}^{2} / \mathrm{s}\right)$. Thiriat et al. ${ }^{18}$ found a mean ADC value of $0.677 \times 10^{-3} \mathrm{~mm}^{2} / \mathrm{s}$ (calculated with $A D C$ values ranging from 0.415 to $0.903 \times 10^{-3} \mathrm{~mm} / \mathrm{s}$ ). In parallel to these reports, our study revealed similar ADC values. Additionally, non-EPI DWI evaluation using ADC 


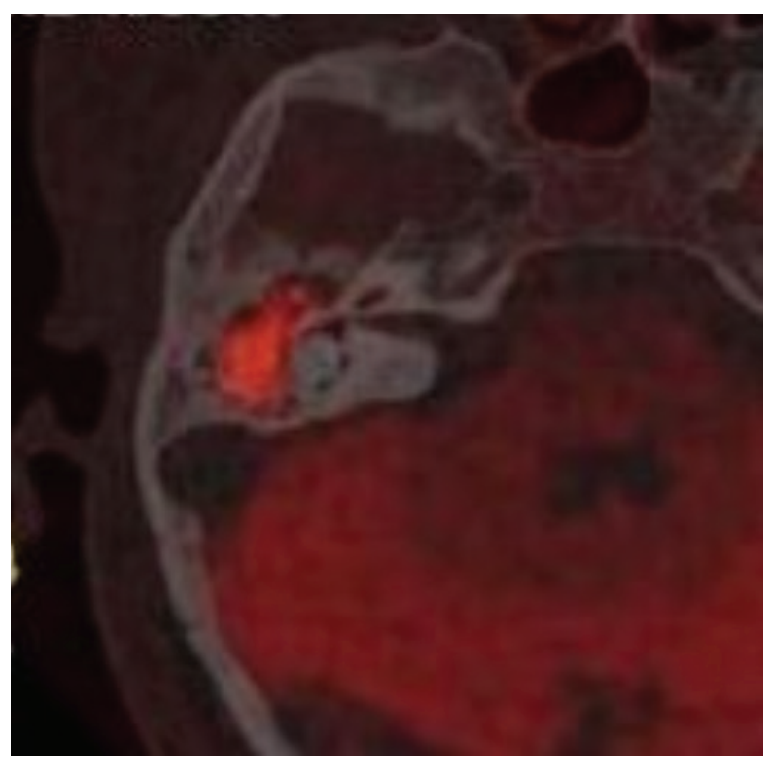

Figure 4. Axial fused image of a patient. There was a big hyperintense lesion on b1000 diffusionweighted magnetic resonance imaging diagnosed as cholesteatoma localized in the tympanic and mastoid cavities. Empyema was found in this localization during the surgery.

values showed high diagnostic accuracy in cholesteatoma detection in our study. Therefore, we suggest that ADC measurements should be used as a powerful parameter to support cholesteatoma diagnosis.

Fusion imaging has recently been proposed for cholesteatoma localization since it prefers less invasive methods such as transcanal endoscopic surgery. In this technique, the anatomical precision of the CT scan replaces the MRI's limited spatial resolution, and the enhancing cholesteatoma becomes dramatically visible ${ }^{11}$.

Locketz et al.12 found that the fusion technique increased the diagnostic sensitivity and accuracy in lesion localization. They revealed that the most accurate results were in the posterior mesotympanum and hypotympanum (100\%), and the least accurate results were in the anterior epitympanum, posterior epitympanum, and anterior mesotympanum (83\%) on lesion localization. Our study revealed similarly quite high diagnostic accuracy rates in estimating lesion localization for five different anatomical regions (range: 79.49$97.44 \%)$. Among the surgically confirmed fusion imaging results, those only in the mesotympanum region were relatively more inconsistently detected than the others as shown in Figure 2. This may be due to the intraoperative misinterpretation of lesions in this rather small area between the epitympanum and the hypotympanum by the surgeons. Providing good exposure with the surgical microscope in the sinus tympani and facial recesses in the mesotympanum during surgery is difficult. Recently, autoendoscopy gained widespread use in otologic surgeries ${ }^{5}$. Using an autoendoscope may be beneficial to evaluate regions with poor surgical exposure. In this study, otologic surgeons did not use autoendoscopes in their operative procedures.

Comparison is difficult and time-consuming due to the disappearance of anatomical marks in the operated ears. Yamashita et al. ${ }^{19}$ revealed no significant differences between the fused images and the intraoperative findings and that the fused images were associated with significantly higher accuracy $(87.5 \%)$ in estimating the cholesteatoma extent. Similarly, our study revealed high accuracy (97.44\%). The anatomical landmarks were disrupted in the earlier surgery, thus radiologically localizing cholesteatoma might be difficult. Hence, the preoperative radiological evaluation before revision surgery may yield limited results because of permanent anatomical changes. Revision surgery may also require more aggressive treatment since they are sometimes performed due to intracranial or intratemporal complications.

\section{Study Limitations}

This study had a couple of limitations. First, the lack of variety among patients with non-cholesteatomatous lesions, such as those with bone dust/powder, wax, or retraction pouch, narrowed the spectrum of the study. Second, we did not evaluate inter-observer or intraobserver variability.

Notwithstanding the relatively limited patient population, this work offers valuable insights into the importance of cholesteatoma imaging. The anatomical precision of the CT scan replaces the MRI's limited spatial resolution, and the enhancing cholesteatoma becomes dramatically apparent.

\section{CONCLUSIONS}

The surgeons' determinations are guided by temporal CT and non-EPI DWI fused images. Therefore, preferring the fusion imaging technique could increase the quality of life by reducing the frequency of patients' exposure to unnecessary operations and reducing costs.

Acknowledgements: The authors would like to thank Associated Professor Dr. Guven Mengu for proofreading and Mrs. Gulsen Gunay to help for statistical evaluation. 


\section{Ethics}

Ethics Committee Approval: The study was approved by the Clinical Research Ethics Committee of the Haydarpasa Numune Training and Research Hospital (decision no: KAEK 2021/265, date: 04.10.2021).

Informed Consent: Signed informed consent forms were waived due to the retrospective cross-sectional design of the study.

Peer-review: Externally and internally peerreviewed.

\section{Author Contributions}

Concept: A.O.B., L.S., A.V., Design: A.O.B., L.S., A.V., Data Collection and/or Processing: A.O.B., L.S., B.A., M.B.E., Analysis and/or Interpretation: A.O.B., L.S., Critical Revision: A.O.B., A.V., S.Z.T., Writing: A.O.B., A.V., S.Z.T.

Conflict of Interest: The authors have no conflict of interest to declare.

Financial Disclosure: The authors declared that this study has received no financial support.

\section{REFERENCES}

1. Stangerup SE, Drozdziewics D, Tos M, et al. Surgery for acquired cholesteatoma in children: long-term results and recurrence of cholesteatoma. J Laryngol Otol. 1998;112:742-9.

2. Kerckhoffs KGP, Kommer MBJ, van Strien THL, et al. The disease recurrence rate after the canal wall up or canal wall down technique in adults. Laryngoscope. 2016;126:980-7.

3. Kim GW, Jung HK, Sung JM, et al. A tiny retraction of the pars flaccida may conceal an attic cholesteatoma. Eur Arch Otorhinolaryngol. 2020;277:735-41.

4. Matsuzawa $S$, lino $Y$, Yamamoto $D$, et al. Attic cholesteatoma with closure of the entrance to pars flaccida retraction pocket. Auris Nasus Larynx. 2017;44:766-70.

5. Campos A, Mata F, Reboll R, et al. Computed tomography and magnetic resonance fusion imaging in cholesteatoma preoperative assessment. Eur Arch Otorhinolaryngol. 2017;274:1405-11.

6. Khemani S, Singh A, Lingam RK, et al. Imaging of postoperative middle ear cholesteatoma. Clin Radiol. 2011;66:760-7.

7. Bennett M, Wanna G, Francis D, et al. Clinical and cost utility of an intraoperative endoscopic second look in cholesteatoma surgery. Laryngoscope. 2018;128:2867-71.

8. Lingam RK, Bassett P. A Meta-Analysis on the Diagnostic Performance of Non-Echoplanar Diffusion-Weighted Imaging in
Detecting Middle Ear Cholesteatoma: 10 Years On. Otol Neurotol. 2017;38:521-8.

9. Khemani S, Lingam RK, Kalan A, et al. The value of non-echo planar HASTE diffusion-weighted MR imaging in the detection, localisation and prediction of extent of postoperative cholesteatoma. Clin Otolaryngol. 2011;36:306-12.

10. Majithia A, Lingam RK, Nash R, et al. Staging primary middle ear cholesteatoma with non-echoplanar (half-Fourier acquisition single-shot turbo-spin-echo) diffusion-weighted magnetic resonance imaging helps plan surgery in 22 patients: our experience. Clin Otolaryngol. 2012;37:325-30.

11. Plouin-Gaudon I, Bossard D, Ayari-Khalfallah S, et al. Fusion of MRIs and CT scans for surgical treatment of cholesteatoma of the middle ear in children. Arch Otolaryngol Head Neck Surg. 2010;136:878-83.

12. Locketz GD, Li PM, Fischbein NJ, et al. Fusion of Computed Tomography and PROPELLER Diffusion-Weighted Magnetic Resonance Imaging for the Detection and Localization of Middle Ear Cholesteatoma. JAMA Otolaryngol Head Neck Surg. 2016;142:947-53.

13. Sharma SD, Hall A, Bartley AC, et al. Surgical mapping of middle ear cholesteatoma with fusion of computed tomography and diffusion-weighted magnetic resonance images: diagnostic performance and interobserver agreement. Int J Pediatr Otorhinolaryngol. 2020;129:109788.

14. Lingam RK, Nash R, Majithia A, et al. Non-echoplanar diffusion weighted imaging in the detection of post-operative middle ear cholesteatoma: navigating beyond the pitfalls to find the pearl. Insights Imaging. 2016;7:669-78.

15. von Kalle T, Amrhein P, Koitschev A. Non-echoplanar diffusionweighted MRI in children and adolescents with cholesteatoma: reliability and pitfalls in comparison to middle ear surgery. Pediatr Radiol. 2015;45:1031-8.

16. Nash R, Wong PY, Kalan A, et al. Comparing diffusion weighted MRI in the detection of post-operative middle ear cholesteatoma in children and adults. Int J Pediatr Otorhinolaryngol. 2015;79:22815.

17. Lingam RK, Khatri P, Hughes J, et al. Apparent diffusion coefficients for detection of postoperative middle ear cholesteatoma on nonecho-planar diffusion-weighted images. Radiology. 2013;269:50410.

18. Thiriat S, Riehm S, Kremer S, et al. Apparent diffusion coefficient values of middle ear cholesteatoma differ from abscess and cholesteatoma admixed infection. AJNR Am J Neuroradiol. 2009;30:1123-6.

19. Yamashita K, Hiwatashi A, Togao O, et al. High-resolution threedimensional diffusion-weighted MRI/CT image data fusion for cholesteatoma surgical planning: a feasibility study. Eur Arch Otorhinolaryngol. 2015;272:3821-4. 